\title{
Pemilihan penyembuhan penyakit melalui pengobatan tradisional non medis atau medis
}

\author{
Choosing the type of healing method
}

\author{
$\underline{\text { Ayu Setyoningsih }}^{1}$ \& Myrtati D. Artaria ${ }^{2}$ \\ 1) Program Studi Antropologi, FIB, Universitas Brawijaya, Malang \\ Jalan Veteran Malang, Kota Malang, Jawa Timur 65145, Indonesia, Phone: +62 341 \\ 575875. Korespondensi: iu.sweet@yahoo.co.id \\ 2) Departemen Antropologi, FISIP, Universitas Airlangga, Surabaya
}

\begin{abstract}
This study regarding the selection of treatment between traditional medicine or medical treatment that is utilized by the community in an effort to cure disease. Doctors and shaman are two professions are known to the public, but using a different way. The aim of this research was to determine the meaning of a healthy and pain for the people of Jeru, know the reasons for choosing the traditional healing methods (shaman) or methods of medical treatment (doctor), and determine the factors that drive to determine the method of treatment. The method used in this study is a qualitative approach. The research location selected is Jeru Village, District Tumpang, Malang. This location was chosen as the study site because in this village still found a system of traditional medicine (shaman), and can still be found some medical personnel and some healers (shaman) are frequently visited by the public. Jeru's people including homogeneous society. Determination of informants consists of 24 informants consisting of offender treatment, the patient, family, and also family health actors. In collecting the data, researchers used observation and interview techniques. Jeru's society looked healthy and sick are people who feel the presence and absence of disturbances in the body when carrying out its activities. The reason for choosing a method of healing is based on trust, severity of illness, and the cause of the disease. The factors that drive a person to determine the treatment method chosen is based on internal and external factors. Internal comes from a person who wants a cure, while external factors derived from the experience of the people or the community who had suffered from the same disease, and healing which had healed. Early action before choosing between traditional healing or healing of the medical treatment itself. If it is the disease getting worse, then the sick person is looking for other relief efforts, which include traditional medicine, or medical treatment.
\end{abstract}

Keywords: medical treatment, traditional medicine/shaman, sick, healthy, healing

\begin{abstract}
Abstrak
Penelitian ini mengenai pemilihan pengobatan antara pengobatan tradisional atau pengobatan medis yang dimanfaatkan oleh masyarakat dalam upaya penyembuhan penyakit. Dokter dan penyembuh adalah dua profesi yang amat dikenal masyarakat, tetapi dengan memakai cara yang berbeda. Tujuan yang ingin dicapai dalam penelitian ini adalah mengetahui makna sehat dan sakit bagi masyarakat Jeru, mengetahui alasan dipilihnya metode penyembuhan tradisional (penyembuh) atau metode pengobatan medis (dokter), dan mengetahui faktor-faktor yang mendorong untuk menentukan metode pengobatannya. Metode yang digunakan dalam penelitian ini adalah pendekatan kualitatif. Lokasi penelitian yang dipilih adalah Desa Jeru, Kecamatan Tumpang, Kabupaten Malang. Dipilihnya lokasi ini sebagai lokasi penelitian disebabkan karena di desa ini masih ditemukan sistem pengobatan tradisional, dan masih bisa ditemukan beberapa tenaga medis dan beberapa penyembuh yang banyak dikunjungi oleh masyarakat. Masyarakat Jeru termasuk masyarakat homogen. Penentuan informan dilakukan dengan purposive, terdiri dari 24 informan yang terdiri dari pelaku pengobatan, pasien, keluarga pasien, dan juga keluarga pelaku kesehatan. Dalam pengumpulan data, peneliti menggunakan teknik pengamatan dan wawancara. Masyarakat desa Jeru memandang orang yang sehat dan sakit adalah orang yang merasakan ada dan tidak adanya gangguan dalam tubuh ketika melaksanakan aktivitasnya. Alasan dipilihnya metode penyembuhan adalah berdasarkan kepercayaan, tingkat keparahan sakit, dan penyebab timbulnya penyakit. Faktor-faktor yang mendorong seseorang untuk menentukan metode pengobatan yang dipilihnya adalah berdasarkan faktor internal dan eksternal. Internal berasal dari diri seseorang yang menginginkan kesembuhan, sedangkan faktor eksternal berasal dari pengalaman orang-orang atau masyarakat di sekitar yang pernah menderita penyakit yang sama, dan penyembuhan mana yang telah menyembuhkannya. Tindakan awal sebelum dipilihnya antara penyembuhan tradisional atau penyembuhan medis yakni pengobatan sendiri. Jika dirasa
\end{abstract}


penyakitnya semakin parah, barulah seseorang yang sakit tersebut mencari upaya penyembuhan lain, yakni antara ke pengobatan alternatif, atau ke pengobatan medis.

Kata kunci: pengobatan medis, pengobatan tradisional, sakit, sehat, sembuh

\section{Pendahuluan}

Setiap manusia pada hakikatnya ingin terhindar dari gangguan apapun, salah satunya adalah kondisi abnormalitas atau keadaan yang menyebabkan seseorang sakit. Hidup sehat merupakan suatu jaminan untuk dapat bekerja dan memenuhi kebutuhan. Sehat merupakan suatu keadaan yang sangat dibutuhkan semua orang, jika seseorang berada dalam situasi sakit, maka ia akan mengalami kendala-kendala dalam melakukan aktivitas sehari-hari (Marimbi 2009).

Agar selalu dalam kondisi tubuh yang sehat itulah, maka manusia senantiasa berusaha semaksimal mungkin untuk menjaga kesehatan, baik kesehatan yang bersifat individu atau pribadi, maupun kesehatan yang bersifat umum, yakni menyangkut lingkungan sekitarnya. Sebab antara kesehatan pribadi dengan kesehatan lingkungan saling mempengaruhi secara timbal balik. Semakin banyak manusia yang memperhatikan pemeliharaan dan peningkatan kesehatan dirinya, maka akan semakin baik pulalah kesehatan masyarakat, begitu juga sebaliknya (Entjang 1993:19).

Upaya seseorang untuk mendapatkan kesehatan merupakan suatu pranata khusus yang terus dipelihara dan dikembangkan pada masa primitif, pemahaman dan kepercayaan tentang kesehatan dipengaruhi budaya dan peradaban primitif pula (Foster dan Anderson 1986:15). Budaya manusia tentang kesehatan juga berkembang, lebih lanjut dijelaskan Foster dan Anderson bahwa pemahaman masyarakat tentang kesehatan berpengaruh terhadap tindakan yang dilakukannya.

Tingkah laku manusia dalam menghadapi masalah kesehatan bukanlah suatu tingkah laku yang acak (random behaviour), tetapi suatu tingkah laku yang selektif, terencana, dan terpola dalam suatu sistem kesehatan yang merupakan bagian integral dari budaya masyarakat yang bersangkutan. Tingkah laku yang selektif tersebut merupakan suatu strategi adaptasi sosialbudaya yang timbul sebagai respon terhadap ancaman penyakit. Perilaku tersebut terpola dalam pranata sosial dan tradisi budaya yang ditujukan untuk meningkatkan kesehatan (Dunn 1976:133-156).

Upaya pemeliharaan dan peningkatan kesehatan untuk menghindari ancaman penyakit diwujudkan dalam suatu wadah pelayanan kesehatan yang disebut sarana kesehatan. Jadi sarana kesehatan adalah tempat yang digunakan untuk menyelenggarakan upaya kesehatan. Upaya kesehatan merupakan setiap kegiatan untuk memelihara dan meningkatkan kesehatan yang dilakukan oleh pemerintah dan atau masyarakat. Hal ini berarti bahwa peningkatan kesehatan ini, baik kesehatan individu, kelompok, atau masyarakat, harus diupayakan (Notoatmodjo 2007).

Sarana kesehatan yang berada di Desa Jeru, Kecamatan Tumpang, Kabupaten Malang sendiri semakin bervariatif, terlihat dari semakin banyaknya praktik pengobatan untuk menyembuhkan pasien-pasiennya yang berasal dari masyarakat desa Jeru maupun luar desa Jeru.Pengobatan adalah suatu usaha untuk penyembuhan penyakit. Umumnya pengobatan ini dilakukan oleh orang yang ahli dalam menanganinya, misalnya saja tenaga medis (dokter) atau penyembuh (dukun). Dokter dan penyembuh adalah dua profesi yang amat dikenal masyarakat, di mana mereka adalah sebagai pekerja-pekerja sosial yang menyelenggarakan upaya penyembuhan seseorang dari penyakitnya, tetapi dengan memakai cara-caranya sendiri (Doni Saputra 2012). Dua profesi itulah yang dimanfaatkan oleh masyarakat desa Jeru untuk menyembuhkan penyakit atau mengatasi keluhan yang ada dalam dirinya.

Perilaku berobat adalah respon individu terhadap penyakit yang diderita, respon tersebut dapat berupa mendatangi rumah sakit, puskesmas, praktek dokter, atau tempat-tempat lain yang dianggap 
dan diyakini mampu membuatnya menjadi sehat. Menurut Rosenstock (1974), perilaku individu ditentukan oleh motif dan kepercayaannya, tanpa memperdulikan apakah motif dan kepercayaan tersebut sesuai atau tidak dengan realitas atau pandangan orang lain. Oleh karena itu, perilaku pencarian pengobatan oleh masyarakat dipengaruhi oleh jumlah dan jenis sarana pelayanan kesehatan yang tersedia di sekitarnya. Pada wilayah yang banyak tersedia sarana pelayanan kesehatan seperti puskesmas, rumah sakit pemerintah dan swasta, balai pengobatan serta praktek dokter, maka pilihan masyarakat semakin beragam untuk melakukan pencarian pengobatan (Lumban-Gaol 2013).

Dalam sistem kepercayaan sehubungan dengan penyembuhan penyakit, peranan dukun menjadi penting. Menjadi penyembuh dapat diperoleh melalui belajar dan keturunan (Geertz 1981:117). Dukun bukan merupakan hal yang baru, karena dukun telah menjadi salah satu alternatif yang menjadi pilihan dalam penyembuhan beberapa penyakit bagi masyarakat Jeru. Istilah dukun berbeda-beda antara satu daerah dengan daerah lain, pada masyarakat Bugis dan Makassar, orang yang ahli mengobati penyakit secara tradisional dipanggil sanro, yang juga berarti dukun (Rahman 2006 dan Said 1996).

Masih banyak masyarakat yang memilih pengobatan alternatif atau tradisional sebagai langkah untuk menyembuhkan penyakitnya, di samping menggunakan penyembuhan medis. Keberadaan dukun juga masih berguna bagi masyarakat sekitar. Bentuk kesehatan alternate (alternatif) dapat memenuhi kebutuhan kesehatan dari segi sosial, psikologi, dan mungkin pula organik, yang bagi beberapa orang tidak berhasil diperolehnya dari dokter maupun dari pelayanan kesehatan yang berkaitan. Dukun memiliki kemampuan tersendiri untuk menyembuhkan pasiennya, yang menggunakan metode yang berbeda dari metode yang digunakan oleh dokter.

Bertolak dari latar belakang di atas, penelitian ini cukup menarik, di satu sisi ingin mendeskripsikan apa sebenarnya yang melatari pemilihan pengobatan ke penyembuh atau dukun, sedangkan di sisi lain, beberapa praktik medis telah menyediakan layanan pengobatan bagi masyarakat. Penelitian ini akan membahas mengenai pemilihan penyembuhan yang tepat bagi masyarakat Desa Jeru, selain itu juga akan mengetahui penyembuhan mana yang dipilih oleh dokter maupun penyembuh (dukun) itu sendiri ketika berada pada kondisi sakit. Hal ini untuk mengetahui sudut pandang pelaku pengobatan dalam memanfaatkan keterampilan yang dimilikinya.

Bagaimana masyarakat di desa Jeru memaknai sehat dan sakit, serta bagaimana cara mereka dalam mengatasi keluhan dalam kesehatannya, apa yang membuat mereka untuk memilih pengobatan baik secara medis maupun secara tradisional? Faktor apa saja yang mendorong untuk menentukan metode pengobatannya tersebut?

\section{Metode Penelitian}

Metode penelitian merupakan bagian yang sangat penting karena menentukan sukses atau tidaknya suatu penelitian. Metode penelitian adalah cara yang digunakan untuk mengumpulkan data di dalam penelitian. Adapun bentuk penelitian ini adalah penelitian lapangan atau field research. Penelitian ini menggunakan pendekatan kualitatif yang sifatnya deskriptif, yakni dengan mendeskripsikan fenomena yang diteliti secara mendalam mengenai pemilihan upaya penyembuhan penyakit antara penyembuhan alternatif atau penyembuhan medis di Desa Jeru, Kecamatan Tumpang, Kabupaten Malang.

Penelitian ini dilakukan pada satu tempat, yakni di desa Jeru, kecamatan Tumpang, Kabupaten Malang. Dipilihnya lokasi ini sebagai lokasi penelitian disebabkan karena di desa ini masih ditemukan sistem pengobatan tradisional, dan masih terdapat beberapa dukun yang memiliki keahlian khusus yang banyak dikunjungi oleh masyarakat. Di desa ini, pengobatan dalam upaya penyembuhan penyakit yang dipergunakan masyarakat bervariasi, ada yang memilih ke dokter, ada pula yang memilih pengobatan melalui dukun. Masyarakat Jeru termasuk masyarakat 
homogen, meskipun mata pencaharian masyarakatnya bervariatif. Di Desa Jeru masih bisa ditemukan beberapa tenaga medis dan beberapa penyembuh.

Menurut informasi yang didapatkan dari masyarakat setempat, penyembuh yang ada di Desa Jeru ini bervariatif, terdiri dari dukun pijat, dukun bayi, dukun jowo, maupun dukun prewangan. Tenaga medis terdiri dari satu dokter, satu bidan, dan dua mantri.Informan kunci dipilih berdasarkan kemampuan menyembuhkan pasien yang paling diminati dan dipercaya masyarakat, difokuskan kepada Mbah Su dan dokter Awan, keduanya memiliki kemampuan tersendiri yang dipercaya oleh masyarakat untuk mengatasi keluhan yang dideritanya. Mbah Su menjadi penyembuh sejak tahun 1960-an, ia menyembuhkan penyakit melalui media daun sirih, kemenyan, dan kembang telon. DokterAwan merupakan tenaga medis yang lebih berpengalaman dan lebih dipercaya banyak pasien dibandingkan dengan tenaga medis lain yang berada di Desa Jeru.Informan dalam penelitian ini terdiri atas 24 informan, yakni Penyembuh/dukun: Mbah Su, pengguna jasa penyembuh/dukun, Pak Rusdi, Bu Siti, Pak Amed, Bu Tumi, dan Pak Edi; keluarga pengguna jasa dukun: Bu Sunah, Pak Obin, Ardi, Pak Santo, dan Bagas; dokter: Pak Awan; pasien: Pak Bagio, Bu Marmi, Rio, Pak Wari, dan Samsul; Keluarga pasien: Bu Sami, Narto, Pak Rino, Pak Nardi, dan Pak Sugik, keluarga dokter dan penyembuh: Yanti dan Bu Rurin.

Teknikyang digunakan untuk mengambil data adalah cara pengamatan (Observation) dan wawancara (Interview), dari pengamatan dan wawancara mendalam terhadap informan kunci akan menghasilkan data primer. Melalui teknik observasi akan menemukan hal-hal yang sebelumnya belum atau tidak diungkapkan oleh mereka selama proses wawancara.Pendekatan etnografi yang digunakan dalam penelitian ini mengacu pada model pendekatan emik, yakni memandang fenomena-fenomena sosial budaya atas dasar sudut pandang masyarakat yang menjadi objek kajian. Penelitian ini juga menggunakan pendekatan etnografi yang bersifat holistik-integratif, yang bertujuan untuk mendapatkan data atas dasar native's point of view (Spradley 1997).

Data dari hasil observasi dan wawancara dilanjutkan dengan proses analisis. Analisis adalah proses menyusun data agar bisa ditafsirkan. Menyusun data berarti menggolongkannya dalam pola, tema atau kategori. Tafsiran dan interpretasi untuk memberikan makna pada analisis, menjelaskan pola atau kategori dan mencari hubungan antara berbagai konsep (Nasution 1988: 126).

Menurut Huberman dan Miles (Denzin dan Lincoln 2009) analisis data terdiri dari tiga sub proses yang saling terkait, yakni reduksi data, penyajian data, dan pengambilan keputusan atau verifikasi.

\section{Hasil dan Pembahasan}

\section{Penyembuhan di Desa Jeru}

Ada beberapa praktek penyembuhan yang berada di desa Jeru, baik penyembuhan non-medis atau alternatif, maupun penyembuhan medis. Kedua macam penyembuhan tersebutlah yang dimanfaatkan oleh masyarakat untuk menyembuhkan penyakit maupun keluhan yang dideritanya. Penyembuhan tersebut antara lain: Penyembuhan alternatif atau penyembuhan nonmedis yang ada di desa Jeru terdiri dari penyembuhan dengan bantuan dukun atau bisa disebut penyembuh. Menurut informasi yang didapatkan dari masyarakat setempat, penyembuh yang ada di desa Jeru ini bervariatif, terdiri dari dukun pijat, dukun bayi, dukun jowo, maupun dukun prewangan. Menurut keterangan dari salah satu orang yang sudah tua di desa Jeru (Mbah Tun), dulu banyak dukun atau penyembuh yang berada di desa ini, namun setelah mereka meninggal, tidak ada sanak saudara yang mau meneruskan keahliannya karena ilmunya terlalu berat atau dalam bahasa Jawa berarti abot.

Suwati dan Siamah adalah dukun bayi, namun karena Suwati sudah tua dan sakit-sakitan, sehingga ia sudah tidak bisa melakukan aktivitas sebelumnya sebagai dukun bayi. Sedangkan 
Siamah hingga saat ini masih exis sebagai seorang dukun bayi, ia juga bisa nyuwuk, nyiwer, dan pelarisan. Misalnya saja ketika ada bayi yang menangis tiada henti namun tidak mengeluarkan air mata, Siamah bisa menyembuhkan bayi tersebut agar bisa tenang kembali. Ia juga membantu nerang udan, serta membantu seseorang yang menginginkan dagangannya laris.Penyembuh yang ketiga bernama Dasri, ia adalah dukun pijat. Ia biasa memijat orang-orang yang mengeluh sakit di badannya, seperti pegal-pegal, linu, dan meriang. Supri juga seorang dukun pijat, namun perbedaannya dengan Dasri, ia biasa disebut sangkal putung, yakni seseorang yang menyembuhkan keluhan di bagian tulang maupun organ geraknya yang mengalami cidera atau patah. Misalnya ia menyembuhkan seseorang yang cidera setelah mengalami kecelakaan, patah tulang, maupun salah urat.

Dukun prewangan yang berada di desa Jeru bernama Supik. Ia biasa membantu seseorang untuk melihat barang-barang yang hilang, mengetahui seseorang yang mengambil barang-barang orang lain, membuat seseorang jatuh cinta kepada orang yang lain, dan sebagainya. Cara ia melakukan prewangan juga unik. Ketika ada seseorang yang datang ke rumahnya, ia mengajaknya ke dalam kamar. Tamunya tersebut sebelumnya diperingatkan agar jangan kaget atau terkejut, dan tidak perlu kromo atau menggunakan bahasa Jawa yang sopan. Setelah itu, Supik nggedruk-nggedruk bantal atau meja sebanyak tiga kali, lalu ia disusupi oleh roh bernama Ning. Ning adalah seorang anak kecil, seketika itu Supik berubah suara. Jadi ia melakukan prewangan tersebut dengan bantuan roh yang menyusupi dirinya.

Dari sekian penyembuhan non-medis atau penyembuhan alternatif yang berada di desa Jeru di atas, fokus penyembuhan alternatif adalah penyembuhan yang dilakukan oleh mbah Su. Pemilihan mbah $\mathrm{Su}$ sebagai informan utama dikarenakan ia sudah menyembuhkan berbagai penyakit sejak beberapa puluh tahun yang lalu, tepatnya sekitar tahun 60-an. Pengguna jasa penyembuhan mbah Su juga banyak, terdiri dari masyarakat Jeru sendiri, maupun orang-orang di luar desa ini. Metode penyembuhannya yakni melalui kembang, kemenyan, dan suruh atau daun sirih. Gaman yang dimilikinya berupa cincin dan keris, kedua gaman itulah yang membantu mbah $\mathrm{Su}$ menyembuhkan penyakit maupun keluhan lainnya yang dialami oleh "pasien" atau pengguna jasanya.

Dari segi sosiologi, orang yang sedang sakit mempunyai peran (roles), yang mencakup hakhaknya (rights), dan kewajiban sebagai orang sakit (obligation). Menurut Becker, hak dan kewajiban orang yang sedang sakit adalah merupakan perilaku peran orang sakit (the sick role behaviour). Perilaku peran orang sakit antara lain (Becker dalam Notoadmodjo 2005):

(a) Tindakan untuk memperoleh kesembuhan; (b) tindakan untuk mengenal atau mengetahui fasilitas kesehatan yang tepat untuk memperoleh kesembuhan; (c) Melakukan kewajibannya sebagai pasien antara lain mematuhi nasihat-nasihat dokter atau perawat untuk mempercepat kesembuhannya. (d) Tidak melakukan sesuatu yang merugikan bagi proses penyembuhannya; (e)Melakukan kewajiban agar tidak kambuh penyakitnya, dan sebagainya;

Perilaku masyarakat dipengaruhi oleh kepercayaan masyarakat terhadap kesehatan. Model kepercayaan kesehatan (The Health Belief Model) menjadi dasar dalam perilaku masyarakat ini, dengan variabel-variabel pada kerangka teorinya adalah persepsi terhadap kerentanan (perceived susceptibility), persepsi terhadap keseriusan sakit (perceived severity), persepsi terhadap manfaat dan rintangan-rintangan (perceived benefits and barriers), serta isyarat atau tanda-tanda pendorong (cues to action) (Lewin 1954, Becker, 1974 dalam Glanz 2002).

Dalam teori penyakit tradisional umpamanya disebutkan sebab itu, antara lain, karena orang tersebut telah melanggar pantangan (taboo) atau telah terjadi gangguan keseimbangan antara unsur panas dan dingin dalam tubuh, sedangkan dalam teori penyakit modern dinyatakan bahwa seseorang itu jatuh sakit karena daya tahan tubuhnya telah berkurang dalam menghadapi agen (perantara) penyakit seperti bakteri dan virus. Dengan kata lain, sistem teori penyakit ini berkenaan dengan klasifikasi dan keterangan sebab-akibat penyakit (Foster \& Anderson 1978:38-39). 
Menurut Foster dan Anderson (1978), konsep penyakit atau etiologi penyakit terdiri dari sistem personalistik dan sistem naturalistik. Sistem personalistik ialah penyakit yang dipercaya disebabkan oleh sesuatu hal di luar si sakit seperti akibat gangguan gaib seseorang (guna-guna), jin, makhluk halus, kutukan, dan sebagainya, sedangkan sistem naturalistik adalah penyakit yang disebabkan oleh sebab alamiah seperti cuaca dan gangguan keseimbangan tubuh (Yin-Yang).

J. Young (1980) membuat model perilaku tentang "pilihan berobat", di mana adaptasi lintas budaya yang terdapat dalam model kepercayaan kesehatan (health believe model) digunakan untuk menjelaskan pengambilan keputusan tentang pengobatan. Perumusan Young (1980) meliputi 4 unsur utama, yakni daya tarik atau gravity, pengetahuan tentang cara-cara penyembuhan popular, kepercayaan, dan kemudahan.

Berdasarkan tiga konsep di atas, yang diawali dengan takaran pemikiran oleh setiap individu, didukung oleh kepercayaan, dengan melihat jenis penyakit dan penyebab dari timbulnya penyakit yang dirasakan, pada akhirnya akan mengarah pada pemilihan penyembuhan yang tepat dan sesuai.

\section{Penyembuhan medis}

Penyembuhan medis terdiri dari beberapa praktik medis yang dibuka di desa Jeru, kecamatan Tumpang, Kabupaten Malang, baik praktik dokter, mantri, maupun bidan. Praktik penyembuhan medis yang ada di desa Jeru antara lain: Ada satu praktek bidan yang berada di desa Jeru, yakni bidan Ida. Bidan Ida pula yang menjadi tenaga medis di Polindes yang terletak di Balai Desa Jeru. Bidan Ida biasa membantu orang-orang yang melahirkan, memeriksa kesehatan ibu hamil dan anak-anak, maupun orang-orang yang memiliki keluhan penyakit ringan seperti pusing, batuk, dan sebagainya.Ada dua praktik mantri atau perawat yang terletak di Jeru gang III, yakni mantri Agung dan mantri Bunga. Kedua mantri ini adalah sepasang suami istri, dan membuka praktik di rumahnya. Seperti halnya praktik yang dilakukan oleh bidan Ida, mantri Agung dan Bunga juga menyembuhkan beberapa penyakit ringan seperti pusing, mag, batuk, dan sebagainya. Namun dari beberapa informasi yang diperoleh dari masyarakat di desa Jeru yang pernah periksa ke kedua mantri tersebut, mereka tidak puas dengan hasil pemeriksaan medis yang dilakukan oleh mereka. Diagnosa yang dilakukan sering salah. Kesalahan tersebut antara lain kesalahan tensi, ada yang dinyatakan darah tinggi, namun ketika periksa di apotek ternyata sebaliknya. Jadi ada beberapa masyarakat yang merasa tidak cocok dan tidak percaya dengan hasil diagnosa kedua mantri tersebut. Selain membuka praktik di rumahnya, mantri Agung juga melayani pasien melalui telepon atau panggilan, jika ada yang membutuhkan pertolongannya, maka ia akan datang ke rumah pasien.

Selain itu, ada praktik dokter gigi yang terletak di Jalan Raya Jeru, milik drg. Hida.Praktek dokter gigi ini berdiri mulai tahun 2011. Dokter Hida membantu menyembuhkan pasien yang menderita penyakit gigi, seperti mencabut gigi, menambal gigi, dan sebagainya.Dari beberapa praktik medis yang berada di desa Jeru seperti yang disebutkan di atas, fokus peyembuhan medis dalam penelitian ini adalah praktik dokter Awan. Pemilihan praktik dokter Awan yang dijadikan sebagai informan utama karena praktiknya telah berlangsung lama, dengan pengalaman yang lebih banyak, dan juga dengan pasien yang lebih banyak dibandingkan dengan praktek medis yang lain. Metode penyembuhan yang digunakan juga unik dan menarik, selain menggunakan metode yang menggunakan berbagai alat medis, dokter Awan juga menggunakan metode penyembuhan melalui do'a.

\section{Antara Mbah Su dan dokter}

Jika anggota keluarganya ada yang sakit, biasanya mbah $\mathrm{Su}$ mencoba menyembuhkannya sendiri, biasanya didamoni atau dipijat, tergantung keluhannya masing-masing. "tapi wong iku gak iso ngilangi klilipe dewe. Aku yo gak iso marasno aku dewe. Lek aku ngroso awakku gak 
penak yo tak posoni (namun seseorang itu tidak bisa menghilangkan sakitnya sendiri. Saya juga tidak bisa menyembuhkan diriku sendiri.Jika saya merasa tidak enak badan, saya atasi dengan berpuasa)", itulah yang dikatakan oleh mbah Su. Meskipun ia seorang penyembuh, namun ia juga tidak bisa menyembuhkan dirinya sendiri, tentu saja ia membutuhkan orang lain untuk menyembuhkannya. Sudah beberapa tahun terakhir, mbah Su terkena penyakit stroke, berawal ketika ia jatuh di kamar mandi, sehingga tubuhnya yang sebelah kanan tidak bisa digerakkan atau bisa dibilang mati separo.

\begin{abstract}
"Aku pirang-pirang tahun iki mesti ngombe obat, aku golek tombo nang dokter. Yo mesti tah aku percoyo nang dokter. Wingenane pirang-pirang dino wetengku loro, aku njaluk mantuku nakokno nang wong pinter ndek kulon iku. Jarene kenek buyutku, wonge njaluk 400 ewu gawe nyabut jalaran ndek wetengku. Lha lapo aku ngetokno duwik sakmono gawe ngono iku. Ancen dasare wonge ilmune sek ndek isorku, aku gak percoyo nang wak Pari iku. Aku lek loro yo mesti nang dokter. Aku luwih percoyo nang dokter timbang nang wong-wong pinter ngono iku. Aku nang dokter yo wis penak an, masio durung iso waras $100 \%$."
\end{abstract}

(beberapa tahun ini saya selalu minum obat, saya mencari kesembuhan ke dokter. Tentu saja saya percaya kepada dokter. Beberapa hari yang lalu saya mengeluh sakit perut, lalu saya meminta kepada menantu saya untuk mendatangi orang "pintar" di sebelah barat rumahnya. Kata orang tersebut saya terkena nenek buyut saya, lalu ia meminta 400 ribu sebagai ganti untuk menghilangkan penyebab penyakit yang menyerang bagian perut saya. Saya pikir untuk apa saya mengeluarkan uang sebanyak itu untuk hal seperti itu. Emang dasarnya orang tersebut memiliki kemampuan di bawahku, saya tidak percaya kepada Pak Pari itu. Kalau saya sakit, saya selalu ke dokter. Saya lebih percaya kepada dokter daripada orang "pintar" seperti itu. Setelah saya ke dokter, saya merasa lebih baikan, meskipun belum sembuh 100\%).

Meskipun mbah Su adalah penyembuh tradisional (penyembuh alternatif), namun ia lebih percaya kepada dokter untuk menyembuhkan penyakit yang ia derita. Selain penyebab penyakitnya lebih jelas, obat yang diberikan oleh dokter dirasa lebih manjur dan memberikan efek yang bisa dirasa lebih cepat. Sebelumnya ia juga pernah mencari kesembuhan kepada penyembuh lain, namun karena mbah Su merasa ilmu yang dimiliki orang lain tersebut masih di bawahnya, maka ia tidak percaya dengan hasil penerawangannya. Ia lebih percaya kepada diagnosa dokter, jadi selama beberapa tahun ini, mbah Su berobat ke dokter. Bahkan ia juga pernah dirawat di puskesmas karena penyakit lambung.

Beberapa anggota keluarga Mbah Su mendukung pemilihan penyembuhan ke mbah Su. Pak Rusdi dan keluarganya percaya dan yakin bahwa Pak Rusdi akan sembuh, dan kesembuhan tersebut ternyata diperolehmelalui perantara mbah Su. Proses pengobatan yang diterima pak Rusdi yakni dipijat, lalu didamoni dengan menggunakan mantra Jawa. Mbah Su tidak mengungkapkan do'a atau mantra apa yang digunakan, mbah $\mathrm{Su}$ juga menjelaskan bahwa mantra tersebut tidak boleh diberitahukan kepada siapapun, baik keluarga maupun orang lain, karena bersifat rahasia.

Informan selanjutnya yang menggunakan jasa penyembuhan Mbah Su adalah bu Siti dan Pak Amed, kedua informan tersebut mengalami keluhan yang sama, yakni perutnya membesar. Sebelum disembuhkan oleh mbah $\mathrm{Su}$, bu Siti telah melakukan upaya penyembuhan kemanamana, baik penyembuhan medis maupun alternatif. "aku biyen iku loro nemen nduk, wetengku gede. Wes golek tombo nandi-nandi tapi pancet ae, ganok olehe, sampek ping 39. Aku kaet ketemu mbah Su iku ndek pasar, kene podo nduwe bedak e. Mbah Su iku wong seng ke-40, alhamdulillah nemu jodone. Waras nduk mari nombo nang wonge". (saya dulu sakit parah, perut saya membesar. Sudah mencari obat kemana-mana tetapi nihil, hingga 39 kali mencari penyembuh. Pertama kali saya bertemu mbah Su itu di pasar, kami sama-sama memiliki toko. Mbah Su itu orang ke-40, Alhamdulillah bertemu obatnya. Sembuh mbak setelah diobati mbah $\mathrm{Su}$ ).

Sebelum melakukan penyembuhan, terlebih dulu mbah Su menerawang penyakit atau penyebab keluhan yang dialami oleh "pasien", apakah penyakitnya termasuk penyakit ringan, atau penyakit berat yang sulit untuk disembuhkan. 
Mbah Su mengetahui hal tersebut melalui daun sirih, kemenyan, keris, dan cincin yang digunakannya. Menurut keterangan dari mbah $\mathrm{Su}$, sambil mengucapkan mantra ataupun do'ado'a tertentu, daun sirih yang dipegangnya tersebut seolah-olah ada tulisannya, meliputi penyebab dan penawar untuk menyembuhkan penyakit yang diderita oleh "pasien", "sakdurunge ono wong mertombo rene, aku iku wes eruh tombo ambek obate. Aku eruh iku yo tekok mimpi (sebelum ada orang yang mencari kesembuhan disini, saya sudah mengetahui penyakit dan obatnya apa. Saya mengetahuinya melalui mimpi)" begitu ulasan mbah Su.

Kebanyakan penyakit yang diderita oleh pengguna jasa Mbah Su adalah penyakit yang tergolong dalam etiologi personalistik, yakni penyakit yang timbul karena adanya unsur yang tidak terlihat.Setelah sembuh, tetangga bu Siti yang bernama pak Amed mengeluh penyakit yang sama, yakni perutnya membesar. Bu Siti pun merekomendasikan pak Amed untuk mertombo (mencari kesembuhan) ke mbah $\mathrm{Su}$, siapa tahu mendapatkan kesembuhan sepertinya, karena sebelumnya bu Siti juga menderita penyakit yang sama. Bu Siti dan Amed sama-sama mendapatkan dukungan dari keluarga, karena anggota keluarganya pun menginginkan kesembuhan seperti sedia kala. Anggota keluarga keduanya juga mengantarkan berobat ke mbah $\mathrm{Su}$, ketika itu, bu Siti dan pak Amed diantarkan oleh anaknya.

Meskipun sudah sembuh, tapi hingga saat ini keduanya masih sering mengunjungi mbah Su, tidak jarang mereka mengajak saudara maupun tetangga yang lain, baik untuk mencari ksembuhan, minta pelarisan, cari jodoh, ingin memiliki keturunan, dan sebagainya.

Informan keempat yakni bu Tumi, ia berobat ke mbah $\mathrm{Su}$ dengan diantarkan oleh puteranya, bernama Santo. Pertama kali ke mbah Su, kondisinya tidak bisa berbicara, bahkan untuk membuka mulutnya saja sulit. Infoman diketahui terkena santet di bagian mulutnya, hingga tidak bisa berbicara. Ia sembuh setelah dua kali berobat ke mbah Su. Selain itu, informan juga menyembuhkan cucunya yang berumur 4 tahun yang bertingkah nakal, yakni tidak bisa diam dan terus merengek-rengek ke ibunya. Cucunya tersebut terkena setan kuda lumping, karena ia sering melihat kuda lumping yang kalap di sekitar tempat tinggalnya. Cucunya sembuh setelah disuwuk oleh mbah Su. Ia diminta oleh mbah Su meletakkan daun sirih yang telah didamoni untuk diletakkan di bawah bantal cucunya, agar cucunya bertingkah normal seperti anak yang lain, dan tidak nakal.

Alasan terbesar dari semua pengguna jasa penyembuhan mbah $\mathrm{Su}$ adalah untuk memperoleh kesembuhan setelah beberapa kali mencari upaya penyembuhan lain, baik medis maupun alternatif namun masih belummemperoleh kesembuhan. Keinginan untuk sembuhlah yang mendorong masing-masing informan untuk mencari penyembuhan yang cocok. Berikut ungkapan pak Rusdi dan bu Siti:

"Nandi-nandi pokok golek waras mbak, yo seng penting yakin lek waras, seng penting iku ekok awake dewe mbak, percoyo lek waras po gak. Nandi-nandi iku golek tombo mbak, yo bismillah ae pokok e. Seng jenenge penyakit iku yo mesti ono tombone, kari kene dewe ae yokpo carane golek tombo iku. Seng digoleki wong loro iku yo mesti pengen waras".

(kemana-mana yang penting mencari kesembuhan mbak, yang penting yakin akan sembuh, yang penting itu berasal dari dirinya sendiri mbak, percaya akan memperoleh kesembuhan atau tidak. Kemana-mana itu mencari kesembuhan mbak, ya pokoknya bismillah saja. Yang namanya penyakit itu ya sudah pasti ada obatnya, tinggal bagaimana kita mencari obat tersebut. Yang dicari orang yang sedang sakit itu, pasti ya ingin sembuh)

\section{Praktik Dokter Awan}

Dokter Awan menjadi tenaga medis sejak tahun 1988, yakni setelah lulus sekolahkesehatan. Faktor sosial yakni untuk menolong orang adalah hal yang melatar belakangi dirinya menjadi seorang tenaga medis. Kini ia menjadi tenaga medis di salah satu rumah sakit di Kota Malang. Selain 
itu, ia juga membuka praktik di rumahnya, ia juga melayani panggilan darurat jika pasien atau keluarga pasien memintanya untuk datang. Selama proses pemeriksaan maupun penyembuhan, dokter Awan menggunakan berbagai alat medis seperti tensi, infus, EKG (alat rekam jantung), stetoskop, suntikan, dan sebagainya. Asal pasien juga bervariatif, ada yang berasal dari desa Jeru sendiri, dan ada juga pasien yang berasal dari luar kota.

Penyakit yang bisa disembuhkan oleh dokter Awan antara lain penyakit ringan seperti diare, panas, sakit perut, hingga penyakit berat seperti stroke, jantung, B24 (HIV), korban kecelakaan, hingga kasus traumatik yang dialami pasien seperti korban pemerkosaan, dan lainlain. Selain menggunakan metode pemeriksaan medis pada umumnya seperti tensi, dan sebagainya, ia juga menggunakan metode penyembuhan lain yakni dengan berdo'a dan sholawat.

Sebelum diperiksa, pasien diminta untuk bershalawat dan memejamkan mata, sambil mengucapkan do'a, dokter Awan melakukan gerakan tangan di atas tubuh pasien mulai ujung kaki hingga ujung kepala. Dokter Awan juga bisa menyembuhkan pasien melalui jarak jauh, yakni via telepon, ia mendapatkan kemampuan tersebut dari guru spiritualnya yang berada di Madura.

Proses penyembuhan jarak jauh melalui telepon yakni, pertama pasien diminta untuk menyentuh atau memegang bagian tubuh yang sakit sambil mengucapkan do'a dan bersholawat. Kemudian Dokter Awan juga mengucapkan do'a sambil melakukan gerakan seperti menyalurkan energi. Proses penyembuhan melalui jarak jauh ini biasa dilakukan karena faktor jarak dan waktu, sehingga pasien tidak bisa berobat langsung ke rumah dokter Awan. Bu Hasnah misalnya, ia juga merupakan kerabat dari dokter Awan. Ketika itu ia berada di Bali, ia merasa kurang enak badan (pegal-pegal), lalu ia telepon dokter Awan untuk menyembuhkan keluhannya. Efek dari penyembuhan jarak jauh tersebut langsung terasa, ditandai dengan berkurangnya rasa sakit yang diderita pasien.

Meskipun kelima informan yang berobat ke dokter Awan di atas memilih penyembuhan medis, namun mereka juga tidak dapat memungkiri bahwa mereka percaya dengan penyembuhan nonmedis atau alternatif. Hal tersebut bisa diketahui dari ungkapan-ungkapan para informan sebagai berikut:

"Lek aku se yo percoyo-percoyo ae nduk. Wong saiki yo akeh wong pinter. Tapi lek lorone sek iso diwarasno ambek dokter yo aku luwih milih nang dokter ae. Luwih eroh genahe loro opo, engkok yo oleh obat, kathek an alhamdulillah aku yo mesti jodo nang Pak Wan. Aku wingenane ngeterno tonggoku nang dukun nduk, wonge nang dukun cekne dadi petinggi. Cekne menang pas pemilihan ngono ikulo. Tapi lek aku dewe sek durung tau nang dukun mbak, wedi lek larang, yo wedi lek gak mandi, aku luwih percoyoan nang seng jelas-jelas ae mbak", ujar Pak Bagio.

Kalau saya sih percaya-percaya saja mbak. Sekarang ini juga sudah banyak orang "pintar". Namun jika penyakitnya masih bisa disembuhkan oleh dokter, ya saya lebih memilih ke dokter saja. Lebih jelas penyakitnya apa, nanti juga mendapatkan obat, lagipula Alhamdulillah saya selalu cocok dengan Pak Wan. Kemarin saya mengantarkan tetangga saya ke dukun mbak, orangnya mendatangi dukun agar lolos menjadi kepala desa atau petinggi agar menang saat pemilu itu lo. Tapi kalau saya sendiri masih belum pernah ke dukun mbak, takut mahal, takut kalau gak berhasil sembuh, saya lebih percaya yang sudah jelas saja mbak, ujar pak Bagio)dapat diketahui bahwa ketertarikan pasien berobat ke Dokter Awan selain berdasarkan metode penyembuhan yang diberikan, juga berdasarkan pribadi Dokter Awan sendiri, yakni dianggap baik, tidak ketus, dan rajin beribadah. Kepribadian Dokter Awan yang dianggap baik oleh masyarakat tersebut, secara tidak langsung menjadi pertimbangan tersendiri bagi pasien untuk melakukan penyembuhan disana. Selain itu, penyembuhan Dokter Awan dianggap lebih jelas dan lebih sesuai untuk mengatasi keluhan pasien, ditunjang dengan pengetahuan dan keterampilan yang telah dimilikinya. 
Namun begitu, meskipun pasien lebih condong ke penyembuhan yang dilakukan oleh Dokter Awan, mereka juga mempercayai penyembuhan non-medis.Persoalan sehat dan sakit sering dikaitkan dengan aktivitas hidup sehari-hari. Mereka memandang bahwa orang yang sehat dan sakit adalah orang yang merasakan ada dan tidak adanya gangguan dalam tubuh ketika melaksanakan aktivitasnya.

Keluhan sakit (illness) berbeda dengan penyakit (disease). Pengertian sakit berkaitan dengan gangguan psikososial yang dirasakan seseorang dan bersifat subjektif, sedangkan pengertian penyakit berkaitan dengan gangguan yang terjadi pada organ tubuh berdasarkan diagnosis medis dan bersifat objektif (Rosenstock 1974). Selain itu, perilaku sehat juga berbeda dengan perilaku sakit.

Perilaku sakit diartikan sebagai segala macam bentuk tindakan yang dilakukanoleh individu yang sedang sakit agar mendapatkan kesembuhan, sedangkan perilaku sehat yakni tindakan yang dilakukan individu untuk memelihara dan meningkatkan kesehatannya, termasuk pencegahan penyakit, perawatan kebersihan diri, olahraga, dan makanan yang bergizi (Sarwono 2012).

Pemilihan penyembuhan didasarkan pada keluhan yang dirasakan oleh masing-masing pasien. Kepercayaan dan penyebab dari penyakit juga menjadi pertimbangan tersendiri, seperti yang dialami oleh bu Tumi, karena ia merasa bahwa penyakit yang dialaminya "aneh", maka ia langsung berobat ke Mbah Su, karena ia beranggapan bahwa dokter tidak bisa menyembuhkan penyakit yang menyebabkan ia tidak bisa berbicara. Lain halnya dengan yang dialami oleh Pak Rusdi, Bu Siti, Pak Amed, dan Pak Edi yang sebelumnya telah berobat ke pengobatan medis namun belum embuahkan hasil, sehingga mereka melakukan upaya penyembuhan lain, yakni pengobatan tradisional.

Skinner (1938dalam Notoadmojo 2003:117) merumuskan bahwa perilaku merupakan respon atau reaksi seseorang terhadap stimulus (rangsangan dari luar). Perilaku seseorang pada situasi tertentu biasanya merupakan akibat dari kebutuhan, tekanan, dan rangsangan dari situasi tersebut, artinya lingkungan sosial di mana individu berada merupakan faktor pendorong dalam pengambilan sikap atau perilaku tertentu. Ketika dalam kondisi atau keadaan sakit inilah masyarakat merasa adanya tekanan-tekanan dalam hidup, sehingga hal ini akan mendorong seseorang untuk mencari berbagai bentuk penyembuhan baik yang dilakukan baik oleh petugas medis maupun non medis atau alternatif (Skinner dalam Notoadmojo 2003:117).

Berkaitan dengan hal ini, dikembangkan sebuah model keyakinan sehat (health believe model)" yang dikembangkan oleh Rosenstock (1974). Dimana model kepercayaan kesehatan ini mencakup empat keyakinan utama (Rosenstock dalam Sudarma 2012). Berdasarkan penjelasan teori tersebut dapat diketahui bahwa sebuah perilaku kesehatan yang ditunjukkan oleh masyarakat Jeru, kecamatan Tumpang, Kabupaten Malang berdasarkan pertimbangan yang bersifat subjektif dari individu setelah menerima nasihat yang ditawarkan oleh orang lain terhadap penyakitnya tersebut. Pertimbangan tersebut dilakukan untuk memperoleh kesembuhan serta terhindar dari penyakit yang sedang dideritanya, selain keinginan di dalam dirinya sendiri untuk sembuh, nasihat yang ditawarkan bisa berasal dari keluarga yang menginginkannya untuk sembuh, dan bisa berasal dari pengalaman orang lain seperti tetangga yang sembuh setelah menderita penyakit yang sama.

Mereka juga percaya dengan pengobatan tradisional (dukun atau penyembuh). Hal tersebut untuk memperoleh kesembuhan setelah upaya penyembuhan medis belum membuahkan hasil. Selain itu, dapat diketahui bahwa pemilihan penyembuhan baik melalui medis maupun alternatif tergantung dari bagaimana masyarakat mempersepsikan sakit yang dialami, dan resiko apa yang nantinya akan diterima sebagai konsekuensi dari penyakit yang sedang dialaminya. Misalnya $\mathrm{Bu}$ Tumi yang memilih penyembuhan tradisional yang dilakukan oleh mbah $\mathrm{Su}$ karena merasa penyakit yang dideritanya bukanlah penyakit biasa, melainkan menyangkut hal-hal di luar manusia, atau dalam hal ini melibatkan agen (makhluk halus) yang tidak terlihat. 
Hasil penelitian menunjukkan bahwa pemilihan upaya penyembuhan penyakit yang sesuai oleh masyarakat juga ditentukan atas persepsi penyebab dari penyakit dan rasa sakit yang diterima oleh masing-masing individu tersebut. Semakin besar sakit yang dirasakan, semakin mendorongnya untuk mencari penyembuhan yang cocok. Ketika seseorang mendapatkan kesembuhan dari tindakan yang mereka ambil, maka jika ia mengalami sakit lagi, ia akan kembali ke penyembuhan sebelumnya, baik ke penyembuhan medis maupun alternatif.

Namun jika seseorang tersebut tidak memperoleh kesembuhan yang diinginkannya dari penyembuhan yang telah dipilihnya, maka ia akan mencari upaya penyembuhan yang lain. Pasien yang melakukan pengobatan di dokter Awan merasa cocok dan baikan setelah diperiksa dan diberi obat olehnya, sehingga ketika mereka berada pada situasi sakit lagi, mereka akan kembali ke dokter Awan, karena sebelumnya mereka sembuh dengan bantuan Dokter Awan. Oleh karena itu meskipun banyak dokter-dokter yang lain, maka ia akan lebih memilih Dokter Awan.

\section{Faktor pendorong dalam menentukan metode penyembuhan yang sesuai}

Faktor internal (faktor pribadi) meliputi diri orang yang sakit tersebut, bisa ditimbulkan ketika seseorang yang sakit ingin memperoleh kesembuhan. Faktor internal juga merupakan faktor penentu tindakan apa yang diambil, dan upaya penyembuhan mana yang akan dipilihnya. Ketika seseorang menginginkan sembuh, maka ia akan melakukan sebuah tindakan untuk mencapai tujuannya tersebut. Hal ini bersifat subjektif, tergantung dari kemauan dari masing-masing individu yang menderita suatu penyakit. Keluarga juga termasuk ke dalam faktor internal yang mendorong seseorang melakukan penyembuhan. Jika seseorang mendapatkan support dari keluarga, maka keinginannya untuk sembuh akan semakin besar, namun jika keluarga bersikap acuh tak acuh dan tidak peduli, maka seseorang yang sakit bukannya mendapatkan kesembuhan, sebaliknya, penyakitnya akan semakin parah. Keluarga sangat menentukan tindakan mana yang akan dilakukan jika seseorang mengalami sakit, karena keluarga lah yang paling dekat dengan masing-masing individu tersebut.

Faktor eksternal meliputi lingkungan, tempat dimana ia tinggal. Lingkungan juga sangat berpengaruh terhadap tindakan seseorang dalam hal memilih upaya penyembuhan. Secara langsung maupun tidak langsung, lingkungan sangat berpengaruh terhadap persepsi penyakit seseorang, dan tindakan apa yang akan diambil. Anjuran maupun nasihat dari masyarakat di sekitarnya menentukan tindakan yang akan diambil, baik ke dokter, ataupun ke penyembuh atau dukun.

Pengambilan keputusan merupakan hal yang paling penting dalam menentukan tindakan seseorang. Pengambilan keputusan ditentukan oleh faktor pendorong yang sudah disebutkan di atas, yakni berasal dari keluarga maupun masyarakat sekitar. Namun tetap diri individu sendirilah yang menentukan tindakan mana yang akan diambilnya. Pengambilan keputusan merupakan sebuah tindakan yang diperoleh melalui pertimbangan-pertimbangan tertentu, sehingga konsekuensi dari tindakan mana yang akan dilakukan, dan apa resiko yang diterima telah dipikirkan sebelumnya.

\section{Simpulan}

Berdasarkan hasil penelitian ini dapat disimpulkan bahwa selain mendatangi layanan kesehatan yang ada, mereka juga percaya dengan pengobatan tradisional (dukun atau penyembuh). Hal tersebut untuk memperoleh kesembuhan setelah upaya penyembuhan medis belum membuahkan hasil. Selain itu, dapat diketahui bahwa pemilihan penyembuhan baik melalui medis maupun alternatif tergantung dari bagaimana masyarakat mempersepsikan sakit yang dialami, dan resiko apa yang nantinya akan diterima sebagai konsekuensi dari penyakit yang sedang dialaminya. 
Masyarakat desa Jeru memandang orang yang sehat dan sakit adalah orang yang merasakan ada dan tidak adanya gangguan dalam tubuh ketika melaksanakan aktivitasnya. Seseorang akan merasa sehat apabila tidak ada keluhan yang dirasakan dalam dirinya, sedangkan sakit yakni kondisi yang membuat tubuh harus banyak istirahat dan tidak mampu menjalankan aktivitas seperti biasanya. Alasan dipilihnya metode penyembuhan yang tepat yakni berdasarkan kepercayaan, tingkat keparahan sakit, dan penyebab timbulnya penyakit.

Ada dua faktor utama yang menentukan perilaku sakit yakni persepsi atau definisi indvidu tentang suatu situasi atau penyakit, serta kemampuan individu untuk melawan serangan penyakit tersebut dengan sebuah tindakan. Tindakan awal sebelum dipilihnya antara penyembuhan tradisional atau penyembuhan medis yakni pengobatan sendiri, seseorang akan berupaya mengatasi keluhannya dengan cara minum jamu, maupun membeli obat di warung atau di apotek. Jika dirasa penyakitnya semakin parah, barulah seseorang yang sakit tersebut mencari upaya penyembuhan lain, yakni antara ke pengobatan alternatif, atau ke pengobatan medis. Pengobatan alternatif merupakan tindakan terakhir jika dirasa penyakit yang diderita sudah tidak bisa disembuhkan melalui pengobatan sendiri maupun pengobatan medis.

Faktor-faktor yang mendorong seseorang untuk menentukan metode pengobatan yang tepat adalah faktor internal dan faktor eksternal. Faktor internal berasal dari diri seseorang yang menginginkan kesembuhan dan support keluarga, sedangkan faktor eksternal berasal dari pengalaman orang-orang atau masyarakat di sekitar yang pernah menderita penyakit yang sama, dan penyembuhan mana yang telah menyembuhkannya. Hasil penelitian menunjukkan bahwa kemampuan dokter dan penyembuh berbeda, penyembuh memiliki kemampuan yang "lebih" untuk menyembuhkan penyakit yang tidak bisa disembuhkan oleh dokter. Namun keberadaan penyembuh (dukun) dan dokter menjadi hal yang penting sebagai sarana menyembuhkan penyakit bagi masyarakat, keduanya saling terkait dan saling membutuhkan satu sama lain.

\section{Daftar Pustaka}

Denzin K N dan Lincoln YS (2009) Handbook of Qualitative Research. Edisi Bahasa Indonesia (Terjemahan Dariyatno dkk). Yogyakarta: Pustaka Pelajar.

Doni Saputra(2012) Sistem Pengobatan Tradisional pada Masyarakat Nagari Sikucur Kecamatan V Koto Kampung dalam Kabupaten Pariaman. Skripsi. Universitas Andalas, Padang.

Dunn FL (1976) "Traditional Asian Medicine and Cosmopolitan Medicine as Adaptive System," in Asian Medical System, C. Leslie (ed), Berkeley: University of California Press

Entjang I (1993) Ilmu Kesehatan Masyarakat. Bandung: PT. Citra Aditya Bakti.

Foster GM dan Anderson (1986) Antropologi Kesehatan. Terjemahan. Jakarta: UI Press.

Geertz C (1981) Abangan, Santri, Priyayi dalam Masyarakat Jawa. Jakarta: Pustaka Jaya.

Glanz K, Rimer BK, \& Vismanath K (2008) Health Behavior and Health Education: Theory, Research, and Practice. San Fransisco: Jossey-Bass

Marimbi H (2009) Sosiologi dan Antropologi Kesehatan. Yogyakarta: Nuha Medika.

Lumban-Gaol T (2013) Pengaruh Faktor Sosiodemografi, Sosioekonomi dan Kebutuhan terhadap Perilaku Masyarakat dalam Pencarian Pengobatan di Kecamatan Medan Kota (Tesis). Medan: Universitas Sumatera Utara.

Nasution S (1988) Metode Penelitian Naturalistik Kualitatif. Bandung: Tarsito.

Notoatmodjo S(2005) Metode Penelitian Kesehatan. Jakarta: Rineka Cipta.

Notoatmodjo S(2007) Promosi Kesehatan dan Ilmu Perilaku. Jakarta: Rineke Cipta

Rahmadewi I (2009) Pengobatan Tradisional Patah Tulang Guru Singa. (Skripsi). Jakarta: Universitas Indonesia.

Rosenstock I (1974) Historical Origins of the Health Belief Model.Health Education Monographs Vol. 2 No. 4. 
Said M B (1996) Dukun. Suatu Kajian Sosial Budaya tentang Fungsi Dukun Bugis Makassar di Kotamadya Ujung Pandang. (Tesis). Jakarta: Universitas Indonesia.

Sarwono S(2012 Sosiologi Kesehatan. Yogyakarta: Gadjah Mada University Press

Spradley PJ (1987) Metode Etnografi. Yogyakarta: PT Tiara Wacana.

Sudarma M(2012) Sosiologi untuk Kesehatan. Jakarta: Salemba Medika.

Young JC (1980) A model of Illness Treatment Decisions in a Tarascan Town. American Ethnologist 7(1): 106-131. 